\title{
Death, Freedom, Isolation and Uncertainty
}

Cordula Holzer, M.D.

Thomas Jefferson University

Follow this and additional works at: https://jdc.jefferson.edu/jeffjpsychiatry

Part of the Psychiatry Commons

Let us know how access to this document benefits you

\section{Recommended Citation}

Holzer, M.D., Cordula (1991) "Death, Freedom, Isolation and Uncertainty," Jefferson Journal of Psychiatry. Vol. 9 : Iss. 1 , Article 13.

DOI: https://doi.org/10.29046/JJP.009.1.012

Available at: https://jdc.jefferson.edu/jeffjpsychiatry/vol9/iss1/13

This Article is brought to you for free and open access by the Jefferson Digital Commons. The Jefferson Digital Commons is a service of Thomas Jefferson University's Center for Teaching and Learning (CTL). The Commons is a showcase for Jefferson books and journals, peer-reviewed scholarly publications, unique historical collections from the University archives, and teaching tools. The Jefferson Digital Commons allows researchers and interested readers anywhere in the world to learn about and keep up to date with Jefferson scholarship. This article has been accepted for inclusion in Jefferson Journal of Psychiatry by an authorized administrator of the Jefferson Digital Commons. For more information, please contact: JeffersonDigitalCommons@jefferson.edu. 


\title{
Death, Freedom, Isolation and Uncertainty
}

\author{
LOVE'S EXECUTIONER \\ \& \\ OTHER TALES OF PSYCHOTHERAPY \\ Irvin Yalom, M.D. \\ New York, Basic Books, 1989 \\ 288 pp. \\ $\$ 19.95$ (Hardcover) \$9.95 (Paperback)
}

\section{Cordula Holzer, M.D.}

The author is probably best known for his contributions to group psychotherapy. However, in his most recent book he attempts to demonstrate the application of existential philosophical ideas to individual psychotherapy with ten patients.

Names of existential psychotherapists that come to mind include Rollo May, Abraham Maslow, Carl R. Rodgers and Gordon Allport. In the 1940s they grew dissatisfied with both psychoanalysis and positivistic behavorism and in the $1950 \mathrm{~s}$ founded a new school they called Humanistic Psychology (1,2). For a short period their national influence was considerable, leading to the establishment of both a journal and a national convention. The founders became increasingly alienated by a 1960's counterculture that embraced humanist psychology and they withdrew their support from the movement. Loosely connected with the existential school and sporadically concerned with their issues were analysts like Karen Horney, Otto Rank and Erich Fromm. Existential psychotherapy is rooted in the philosophy of existentialism which begins with the Dane Soren Kierkegaard (1813-1855) and leads to the 20th century philosophers Jean Paul Sartre and Martin Heidegger. Probably more influential than any of the above are the great novels by Dostoevsky, Tolstoy and Kafka that captured the timeless and honest truths of the human experience.

What is the existential paradigm? Out of despair, when facing the finiteness of the self, the individual becomes aware of self, is self, and understands self. We are doomed to be free, to be responsible for the choices we make; we are born alone and we will die alone in a world of uncertainty and meaninglessness. Thus, existential psychotherapy deals with the "ultimate concerns," as Yalom calls them (3). These basic precepts reveal clearly that the existential view deviates significantly from mainstream psychiatry. While its language is psychologically alien, there is also no room for empirical research because the existentialist postulates that man is greater than the sum of his parts. Man cannot be understood from the study of partfunctions, a notion that is not consistent with the premise that empirical research is the method of choice in determining how and what we know. The struggling 
individual dealing with ultimate concerns is also not the instinctively driven, unconsciously determined being a la Freud. Irvin Yalom has outlined the limits of existential psychotherapy as follows: "Existence is inexorably free and, thus, uncertain. Cultural institutions and psychological constructs often obscure this state of affairs, but confrontation with one's existential situation reminds one that paradigms are self-created, wafer thin barriers against the pain of uncertainty." (4)

Given the fact that the existential paradigm has primarily European roots Yalom's book offers the opportunity to study his adaptations in a distinctly American setting and to decide whether the existential approach can make a contribution to our understanding of patients.

The author writes a clear, jargon free language, and reading proceeds so smoothly that one wonders whether there is anything significant going on in these "Tales of Psychotherapy."

Yalom introduces us to ten everyday people, very much like those a resident treats in any given outpatient setting. Their treatments are brief; none exceeds a years duration. The author foregoes the exploration of an underlying psychic structure to focus instead upon the relationship between him and the patient in the here-and-now (p. 8). In "Therapeutic Monogamy" the author notes: "But over the years I have learned that the therapist's venture is not to engage the patient in a joint archeological dig. No, a therapist helps a patient not by sifting through the past but by being lovingly present with that person; by being trustworthy, interested; and by believing that their joint activity will ultimately be redemptive and healing"' (p. 227).

True to the existential approach the therapist expects the patient to assume responsibility for his life's predicament as the prerequisite to change. Yalom's therapeutic interventions to this end range far afield from interpretation. Where the patient's understanding does not lead to action he uses unorthodox measures to influence the patient. In "Love's Executioner" Yalom calls in his elderly patient's former lover for a joint session in an attempt to resolve her love-obsession. In "Three Unopened Letters" he makes home visits to see his psychotic patient. In "Do Not Go Gentle" the author stores love letters for the patient in his office. In short, Yalom draws upon many resources to influence his patients.

The narrative of his cases develops on four different levels i.e. the patients history, the phenomenology of the patient's pathology, the therapist's continuous self-reflective discourse with himself, and the interaction between patient and therapist. Yalom's self-revelations are relentless.

In the case of "The Fat Lady" he dares and probes a seething countertransferance towards obese women whose jaws he would like to wire shut (p. 89). Whether Yalom's self-revelations are helpful in understanding his approach remains questionable throughout the book. However, it is in his portraits of both his clients' and his own experience that the author sears the readers memory. He has shown us that ultimately we are no different from our patients, and that "patienthood is ubiquitous" (p. 14) and that the struggle with death, bereavement, failure and uncertainty is ours 
as well. In this regard Yalom is a true humanist. He offers little comfort other than the Socratic credo that the unexamined life is not worth living. (p. 154)

Overall, the author has made palatable material that is bitter and preferentially screened by denial. Even as one questions his technique and the many problems that it brings, he provokes and stimulates further thought.

\section{REFERENCES}

1. May R: Man's Search For Himself. New York, N.Y.: W.W. Norton \& Company, 1953

2. May R, ed: Existential Psychology. New York, N.Y.: Random House, Inc., 1969

3. Yalom I: Existential Psychotherapy. New York, N.Y.: Basic Books, Inc., p. 8, 1980

4. Id., p. 26 